\title{
Kemiskinan dan Putus Sekolah
}

\section{Lisa Hikmah}

\author{
Hidayah Quraisy \\ Universitas Muhammadiyah Makassar \\ hidayahquraisy@unismuh.ac.id
}

\author{
Jamaluddin Arifin \\ Universitas Muhammadiyah Makassar \\ jamaluddinarifin@unismuh.ac.id
}

\begin{abstract}
ABSTRAK
Masalah utama dalam penelitian ini adalah faktor-faktor yang menyebabkan putus sekolah pada anak petani di Desa Kampung Beru Kabupaten Takalar dan bagaimana bentuk peran sosial anak putus sekolah dalam membantu ekonomi keluarga. Penelitian bertujuan mengetahui faktor- faktor penyebab putus sekolah pada anak petani dan bentuk peran sosial anak putus sekolah dalam membantu ekonomi keluarga. Penelitian ini adalah jenis penelitian kualitatif deskriftif, melalui pendekatan studi kasus. Hasil penelitian menunjukkan bahwa: (1) faktor yang menyebabkan anak petani di Desa Kampung Beru putus sekolah karena tidak mampu membiayai anaknya, ada juga anak yang memang tidak mau sekolah, kurangnya perhatian orang tua, hal demikian terjadi karena penghasilan yang tidak menentu. (2) Peranan anak dalam membantu ekonomi keluarga di Desa Kampung Beru Kabupaten Takalar dapat dilihat dari keberadaan anak dalam keluarga, peranan anak sangat berpengaruh, sebab tingkat pendapatan keluarga ada perubahan jika dibandingkan dari sebelumnya, karena sebelum anak bekerja pendapatan keluarga sangat minim. Maka dari itu pula anak putus sekolah karena faktor ekonomi rendah dan tidak ada biaya, sehingga anak memutuskan putus sekolah dan punya inisiatif untuk membantu orang tua dan mencari kerja. Dalam hal ini membantu dan menutupi kekurangan ekonomi keluarga menunjukkan kondisi keluarga petani rata-rata serba kekurangan dengan melihat penghasilan yang didapatnya sehingga membutuhkan peran anak.
\end{abstract}

Kata Kunci : Kemiskian, Putus Sekolah, Anak petani.

\section{PENDAHULUAN}

Pada umumnya keluarga yang ada di Indonesia terdapat dua masalah yang sangat penting diperhatikan yaitu masalah pendidikan dan masalah kebutuhan ekonomi keluarga. Khususnya pendidikan, kadang suatu keluarga menyerahkan bentuk pendidikannya pada bentuk pendidikan formal. Seperti sekolah dasar sampai perguruan tinggi. Akan tetapi masalah pendidikan di Indonesia sangat urgen karena melihat angka putus sekolah dan memilih menjalani hidup terlibat roda-roda ekonomi dalam memenuhi kebutuhannya. Dalam setiap masyarakat akan dijumpai berbagai bentuk kelompok social baik dalam bentuk keluarga maupun kelompok social lainnya. Keluarga yang merupakan unsur dan kelompok terkecil dalam masyarakat adalah terdiri dari suami, istri beserta anak-anaknya 
yang belum menikah.Keluarga juga disebut rumah tangga yang merupakan wadah pergaulan dalam kehidupan yang melembaga.

Setiap anggota keluarga memiliki peranannya masing-masing. Adapun peranannya berbeda mulai dari ayah sebagai kepala keluarga yang bertugas mencari nafkah untuk mencukupi kebutuhan keluarga dan ibu mempunyai peranan sebagai pengelolah dan pengatur rumah tangga, menyelesaikan pekerjaan rumah tangga, dan mengasuh serta mendidik anak. Anak sebagai pelanjut generasi yang nantinya bisa menjadi orang yang mandiri. Hanya dengan generasi penerus yang terdidik dan cerdas serta bermoral, maka hari depan bangsa bisa dibayangkan titik terangnya. Namun pendidikan di Indonesia semakin lama semakin mahal. Program pendidikan gratis yang diterapkan pemerintah pun masih dianggap belum efektif dalam meningkatkan pendidikan di Indonesia. Wajar bila banyak anak usia sekolah yang terpaksa putus sekolah akibat masalah dana. Banyak anak putus sekolah dan menjadi pekerja anak disebabkan karena biaya pendidikan di Indonesia masih sangat mahal di anggap terlalu mahal dan tak terjangkau oleh sebagian kalangan masyarakat.

Pekerja anak di Indonesia bukanlah hal yang baru. Pekerja anak awalnya merupakan tradisi atau budaya membantu orang tua. Sebagaian besar orang tua menganggap bahwa memberikan pekerjaan kepada anak-anak sejak dini adalah proses belajar, agar mereka bisa lebih menghargai kerja dan tanggung jawab. Selain itu, anak bekerja diharapkan dapat membantu mengurangi beban kerja dan menambah penghasilan keluarga. Begitupun mengenai hubungan anak dengan lingkungannya, maka lingkungan pertama yang berhubungan dengan anak adalah orang tuanya, saudara-saudaranya, serta mungkin kerabat dekatnya yang tinggal serumah. Melalui lingkunagan itulah anak mengenal dunia sekitarnya dan pola pergaulan hidup yang berlaku sehari-hari, melalui lingkungan hidup itulah anak mengalami proses sosialisasi awal.

Di Desa Kampung beru Kabupaten Takalar, mempunyai pandangan dalam sebagian masyarakat yang melihat bahwa pendidikan adalah bukan solusi dalam meningkatkan taraf hidup sehingga kadang terjadi banyak anak yang mengambil peranan dalam membantu ekonomi keluarga, hal ini juga termotivasi untuk mandiri dan dapat memberikan kontribusi dalam peningkatan taraf ekonomi keluarga. Kecenderungan pandangan diatas lahir dari kalangan masyarakat tani. Anak dalam keluarga petani cenderung membantu dan mengololah lahan pertanian mereka, pada umumnya sosial ekonomi masyarakat petani memiliki sistem kerja yang sangat homogen terlebih pada rutinitas kerja yang tidak membutuhkan skill, umumnya petani bekerja di sawah dengan 
sistem menanam yang dilakukan pada umumnya dua kali dalam setahun, dari semua orang kadang mengajarkan anaknya sejak dini untuk membantu di sawah dengan harapan kerjanya ringan dan mendapatkan hasil pertanian yang melimpah.

\section{KAJIAN TEORI}

Konsep masalah sosial berkaitan dengan norma dan institusi sosial, artinya sesuatu ingin dianggap sebagai masalah sosial karena menyangkut hubungan manusia dengan nilai-nilai dan merupakan ganguan terhadap tujuan kehidupan masyarakat. Masalah sosial atau sosial problems ialah setiap keadaan yang dianggap oleh seluruh atau sebagian warga masyarakat sebagai suatu keadaan yang tak dikehendaki. Tak dapat ditoleransi atau dianggap ancaman bagi nilai-nilai masyarakat, sehingga memerlukan tindakan masyarakat untuk menyelesaikannya. Kemiskinan adalah keadaan di mana terjadi kekurangan hal-hal yang biasa untuk dipunyai seperti makanan, pakaian, tempat berlindung dan air minum, hal-hal ini berhubungan erat dengan kualitas hidup . Kemiskinan kadang juga berarti tidak adanya akses terhadap pendidikan dan pekerjaan yang mampu mengatasi masalah kemiskinan dan mendapatkan kehormatan yang layak sebagai warga negara. Kemiskinan merupakan masalah global. Sebagian orang memahami istilah ini secara subyektif dan komparatif, sementara yang lainnya melihatnya dari segi moral dan evaluatif, dan yang lainnya lagi memahaminya dari sudut ilmiah yang telah mapan. Istilah "negara berkembang" biasanya digunakan untuk merujuk kepada negara-negara yang "miskin".

Menurut Sulistiyanti dalam Rudyansyah (2014), kemiskinan memiliki sifat plural sehingga kemiskinan menunjukkan adanya sekelompok orang yang serba kekurangan. Masyarakat subsistem yang tidak berpenghasilan atau berpenghasilan tapi rendah, bisa jadi tidak merasa miskin karena mereka merasa sudah terpenuhi kebutuhannya. Sebaliknya penduduk urban yang berpenghasilan sedang mungkin merasa selalu kekurangan karena gaya hidup hedonis yang mereka jalani atau lingkungan budaya tidak sehat yang mereka hadapi (misalnya seperti perangkap narkoba ataupun judi). Dalam hal ini meski kelihatannya mereka berkecukupan, namun apabila selalu merasa kekurangan, mereka bisa dikatakan miskin Bappenas dalam Anindiyahpratiwi (2014) mendefinisikan kemiskinan sebagai kondisi di mana seseorang atau sekelompok orang, laki-laki dan perempuan, tidak mampu memenuhi hak dasarnya untuk mempertahankan dan mengembangkan kehidupan yang bermartabat. Hak-hak dasar masyarakat antara lain : terpenuhinya kebutuhan pangan, 
kesehatan, pendidikan, pekerjaan, perumahan, air bersih, pertanahan, sumber daya alam dan lingkungan hidup, rasa aman dari perlakuan atau ancaman tindak kekerasan, dan hak untuk berpartisipasi dalam kehidupan sosial-politik, baik bagi perempuan maupun laki-laki.

Putus sekolah (dalam bahasa Inggris dikenal dengan Drof out) adalah proses berhentinya siswa secara terpaksa dari suatu lembaga pendidikan tempat dia belajar. Pengertian anak putus sekolah adalah seorang anak usia sekolah antara 7 sd 21 tahun yang tidak bersekolah karena tidak mampu membayar biaya sekolah sebab keluarganya miskin sebagian besar menjadi pekerja anak, termasuk anak jalanan dan sebagian lagi menganggur. Setiap orang tua menginginkan anak-anaknya cerdas, berwawasan luas dan bertingkah laku baik, berkata sopan dan kelak suatu hari anak-anak mereka bernasib lebih baik dari mereka baik dari aspek kedewasaan pikiran maupun kondisi ekonomi. Setelah keluarga, lingkungan kedua bagi anak adalah sekolah. Di sekolah, guru merupakan penanggung jawab pertama terhadap pendidikan anak sekaligus sebagai suri teladan. Sikap maupun tingkah laku guru sangat berpengaruh terhadap perkembangan dan pembentukan pribadi anak. Putus sekolah adalah proses berhentinya siswa secara terpaksa dari suatu lembaga pendidikan tempat dia belajar maksudnya anak dari sebuah lembaga pendidikan formal yang di sebabkan oleh berbagai faktor : Kemiskinan, Pendapatan Seseorang yang rendah, Pengangguran, Banyaknya orang yang tidak bekerja, kekacauan dalam keluarga, masalah-masalah yang ada dalam keluarga, pandangan sosiokultural keluarga dan masyarakat tentang penting atau tidaknya sekolah, Anggapan bahwa perempuan sebaiknya tidak bersekolah terlalu tinggi.

Menurut Soedjono Dirdjosisworo dalam Halifah (2007) Peranan sosial adalah suatu cara atau perbuatan atau tindakan seorang individu dalam usaha memenuhi tanggung jawab hak-hak dari status sosialnya, maka seseorang akan terlibat menjalankan atau tidaknya kegiatan-kegiatan yang sesuai dengan status sosialnya. hal ini dapat terlihat dari peranan individu yang berbeda sekaligus dalam suatu status sosial yang sama”. Dengan demikian peran yang melekat pada diri seseorang harus dibedakan dengan posisi atau tempat seseorang dalam masyarakat (sosial-position) merupakan unsur statis yang menunjukkan tempat individu dalam organisasi masyarakat. Sedangkan peran lebih banyak menunjuk pada fungsi, artinya seseorang menduduki suatu posisi tertentu dalam masyarakat dan menjalankan suatu peran.

Sebagaimana dikemukakan oleh J. Dwi Narkowo-Bagong Suyanto, suatu peranan paling sedikit mencapai tiga hal, yaitu: (a) Peran meliputi norma-norma yang 
dihubungkan dengan posisi atau tempat seseorang dalam masyarakat. (b) Peran adalah suatu konsep ikwal apa yang dapat dilakukan oleh individu dalam masyarakat. (c) Peran dapat dikatakan sebagai perilaku individu yang penting bago struktur sosial masyarakat. Hubungan sosial individu berkembang karena adanya dorongan rasa ingin tahu terhadap segala sesuatu yang ada didunia sekitarnya. Dalam perkembangannya, setiap individu ingin tahu bagaimanakah cara melakukan hubungan secara baik dan aman dengan dunia sekitarnya, baik yang bersifat fisik maupun sosial. Hubungan sosial diartikan sebagai "cara-cara individu bereaksi terhadap orang-orang disekitarnya dan bagaimana pengaruh hubungan itu terhadap dirinya" Menurut Anna Alisyahbana, dkk, (2004: 85). Hubungan sosial ini menyangkut juga penyesuaian diri terhadap lingkungan, seperti makan dan minum sendiri, berpakaian sendiri, menaati peraturan, membangun komitmen bersama dalam kelompok atau organisasinya, dan sejenisnya.

Dewasa ini memiliki anak merupakan salah satu pilihan diantara pilihan lain dalam keluarga. Beberapa survey memperlihatkan kecenderungan untuk memiliki anak dalam keluarga bukan lagi suatu kewajiban, melainkan hanya satu pilihan. Hal ini yang membawa sebagian masyarakat memiliki banya anak sudah bukan jamannya lagi, 2 anak cukup hal ini juga melihat program pemerintah yang menekan jumlah penduduk. Secara biologis penurunan jumlah anak pada keluarga dimungkinkan oleh terjadinya perubahanperubahan diluar keluarga. Pada masyarakat tradisional, anak merupakan asset ekonomi keluarga yang dapat menjalankan fungsi dan peran-peran ekonomi. Namun keluarga saat ini anak sebagai beban ekonomi bersifat homogen. Dalam hubungan sosial anak pasti melahirkan pertanyaan dibenak kita, apakah anak merupakan hal yang berhubungan dengan milik dirinya sendiri, milik orang tua, atau hanya mahluk titipan kepada yang maha kuasa.

Syamsu Yusuf (2007) menyatakan bahwa: "Perkembangan sosial merupakan pencapaian kematangan dalam hubungan sosial. Perkembangan sosial dapat pula diartikan sebagi proses belajar untuk menyesuaikan diri terhadap norma-norma kelompok, moral dan tradisi ; meleburkan diri menjadi satu kesatuan dan saling berkomunikasi dan kerja sama”. Menurut (Kartohadikoesoemo, 1984 : 16) sebagai berikut: Desa adalah 'kesatuan masyrakat hukum yang memeiliki batas-batas wilayah yang berwewenang untuk mengatur dan mengurus kepentingan masyarakat setempat, berdasarkan asal usul dan adat istiadat setempat yang diakui dan dihormati dalam sistem pemerintahan NKRI"' (PP 72/ 2005). 
Sebagai statika, desa terbentang dalam aspek geografis, maka ia terdefinisikan sebagai permukaan mulai dari pesisir dan pulau kecil, persawahan dan dataran rendah, hingga dataran tinggi dan pinggir hutan, yang didalamnya manusia berinteraksi dengan buminya. Sebagai statika , desa terbentang dalam aspek ekonomis, maka ia didefenisikan sebagai ruang produksi, distribusi, dan konsumsi yang didalamnya berinteraksi manusia yang hendak memenuhi kebutuhannya ditengah keterbatasan sumberdaya.

Desa mengalami pembangunan tidak lagi hanya oleh konstribusi aktor negara. Agen pembanguna telah muncul dari beragam pihak pengambil kebijakan, perencanaan sektoral/daerah, peneliti dan tenaga ahli, penyuluh dan pendamping masyarakat,investor swasta, tenaga konsultan, agenda donor serta prakarsa swadaya masyarakat desa sendiri. Desa persawahan memiliki nilai srategis dalam sejarah bangsa indonesai karena posisinya sebagai pusat revolusi hijau. Pada tahun 1970-an, ketika orde baru mengimplementasikan Repalita ( Rencana Pembangunan Lima Tahun) dari RPJPT-1 ( Rencana Pembangunan Jangka Panjang Tahap Pertama), revolusi hijau adalah wacana dominan. Revolusi hijau menjelma sebagai kelanjutan dari revolusi kemerdekaan dan dengan itu spirit revolusi tetap bergelora dalam mengisi kemerdekaan. Revolusi hijau merupakan katup pengaman dari ancaman revolusi sosial akibat krisis pangan pada awal pembanguna indonesia . saat itu produksi pangan sangat rendah dan muncul ancaman kelaparan, menyusul krisis sosial pada masyarakat terutama di jawa, terkait peristiwa G-30-S/PKI dan pembersihan elemennya sesudah itu. Sementara itu, pertembuhan penduduk cenderung meningkat, indonesia dalam ambang ledakan populasi. Desa persawahan dicirikan oleh tekanan populasi yang tinggi penduduknya tumbuh lebih tinggi dibanding tipe desa lain sehingga tekanan populasi amat berpengaruh pada dinamika sosial ekonomi dan budayanya. Pada tipe desa inilah pertembuhan penduduk memaksa warga berimigrasi ulang alik ataupun permanen ke pusat kota bahkan bertransmigrasi. Dalam hal inovasi dari luar, desa persawahan lebih cepat menerimah dibandingkan desa pedalaman dan dataran tinggi serta desa pesisir dan pulau kecil. Sehingga dapat dibayangkan betapa desa ini telah mengalami perubahan sosial-ekonomi-budaya dibalik posisinya sebagai pusat revolusi hijau. Peningkatan produksi dan pendapatan telah berlangsung signifikan akibat nilai tambah dalam penggunaan sarana dan teknologi pertanian modern. Dibalik ciri itulah desa persawahan dan dataran rendah terpresentasikan sebagai yang pusat atau yang dekat dengan pusat serta diprioritaskan dalam pembangunan. Bila konstruksi sosial atas ruang menempatkan kota sebagai pusat maka desa persawahanlah yang dekat dengan pusat tersebut. Bila ditanyakan yang mana pula pada berbagai tipe desa di Indonesia, maka 
persawahanlah jawabannya. Ini semua karena tipe desa inilah yang prioritaskan pembangunan.

Keluarga inti dapat kita definisikan dengan keluarga atau kelompok atau unit terkecil dalam masyarakat yang terdiri dari ayah, ibu dan anak-anak yang belum dewasa atau belum kawin. Sedangkan keluarga luas adalah satuan keluarga yang meliputi lebih dari satu generasi atau suatu lingkungan kaum keluarga yang lebih luas dari pada hanya ayah, ibu dan anak-anak yang kawin yang memisahkan diri dari orang tuanya atau keluarga intinya. Menurut Emile Durkheim menyebut keluarga perkawinan ini sebagai "conjugal family" yakni suatu inti dari pasangan suami istri dan keturunan-keturunan mereka yang dilindungi oleh lapisan-lapisan keluarga yang agak jauh. Peran suami dan istri dalam memenuhi kebutuhan ekonominya secara tradisional memandang bahwa lakilaki dan wanita secara badaniah mempunyai perbedaaan. Dengan demikian, sewajarnya wanita hidup dilingkungan rumah tangga. Wanita diberi tugas mengandung, melahirkan, menyusui, membesarkan anak, dan memberi perhatian terhadap suami dimana tugas ini tidak bisa digantikan oleh orang lain. Adapun laki-laki mempunyai tugas pergi keluar rumah mencari nafkah bagi keluarganya.

\section{METODE PENELITIAN}

Jenis penelitian yang dilakukan adalah penelitian kualitatif deskriptif yang bertujuan memahami tentang kemiskinan dan putus sekolah ( study kasus anak petani di Desa Kampung Beru Kabupaten Takalar). Informan ditentukan secara purposive sampling, teknik pengumpulan data yaitu observasi, wawancara, dan dokumentasi, kemudian dianalisis melalui tahapan pengumpulan data, reduksi data, penyajian data, penarikan kesimpulan dan menggunakan tehnik pengabsahan data, triangulasi sumber, waktu dan tehnik.

\section{PEMBAHASAN}

Fenomena putus sekolah bukanlah hal yang hanya terjadi di Desa kampung Beru, akan tetapi fenomena ini marak dibahas atau diperbincankan di seluruh lapisan masyarakat yang menyadari bagaimana pentingnya pendidikan. Hal ini disebabkan oleh ketidak pahaman dari beberapa beberapa orang tua yang salah mempersepsikan pendidikan bagi anaknya, yang beranggapan bahwa pendidikan hanya bertujuan untuk menjadi seorang guru ataupun tentara,polisi,perawat,bidan dan lain sebagainya. Terkhusus beberapa orang tua atau masyarakat yang ada di Desa Kampung dimana 
segelintir orang tua hanya memahami sekolah hanya sekedar untuk belajar membaca dan menulis semata agar tidak mudah tertipu dengan orang lain. Sehingga kita sering melihat ada orang tua yang memberhentikan anaknya dengan maksud akan lebih berguna jika anaknya membantu bekerja di sawah atau memeliharahewan ternak.

Persepsi orang tua akan pentingnya sekolah sampai menamatkan suatu tingkat pendidikan tertentu bagi sang anak terasa masih kurang terutama di Desa Kampung Beru yang bermata pencaharian sebagai petani sebagian orang tua di daerah ini beranggapan bahwa lebih baik anak mereka bekerja di sawah dari pada sekolah karena ketidak mampuan atau jauhnya jarak sekolah yang tidak bisa ditempuh dengan jalan kaki sehingga harus mengeluarkan ongkos untuk sampai ketempat tujuan.

Dari hasil penelitian maka penelitian dapat mengetahui bahwa ada beberapa faktor yang menjadi penyebab terjadinya penomena putus sekolah yang marak terjadi di Desa Kampung beru Kabupaten Takalar. Selain letak Desa yang sedikit terpencil hal lain yang tak kalah penting adalah pemahan sebagian masyarakatnya akan pentingnya pendidikan masih sangat kurang, sehingga hal ini sangat berpengaruh terhadap minat orang tua untuk menyekolahkan anaknya dalam ini menyelesaikan sekolah anaknya atau bahkan untuk melanjutkan pendidikan anaknya kejenjang yang lebih tinggi. Misalnya tingkat pendidikan dan pola hubungan masyarakat, dimana anak diberikan beban untuk membantu orangtua dalam mencari uang dan mengurus rumah tangga. Menurut Soedjono Dirdjosisworo dalam Halifah (2007) Peranan sosial adalah suatu cara atau perbuatan atau tindakan seorang individu dalam usaha memenuhi tanggung jawab hak-hak dari status sosialnya, maka seseorang akan terlibat menjalankan atau tidaknya kegiatan-kegiatan yang sesuai dengan status sosialnya. hal ini dapat terlihat dari peranan individu yang berbeda sekaligus dalam suatu status sosial yang sama. Jadi, dapat dikatakan bahwa anak memiliki peranan yang sangat penting dalam meningkatkan status sosial ekonomi keluarga dengan cara membantu keluarga meningkatkan pendapatan keluarga. Padahal kalau dipikir, status sosial ekonomi keluarga bukan hanya dinilai dari pendapatan ekonomi tetapi terkait dengan pola hubungannya dengan masyarakat. Pada masyarakat petani, anak bukan saja berperan mebantu orang tua utuk menggarap sawah/kebun sebagai sumber mata pencaharian pokok keluarga, tetapi anak harus berperan dalam membuat orang tua dalam berkembang pola pikir sesuai dengan pekembangan zaman dan pengetahuan yang dimilikinya hanya dapat membantu orangtua.

Pada dasarnya anak bermotivasi untuk membantu keluarga karena kondisi kebutuhan semakain meningkat, yang dulunya hanya mencukupi dengan kebutuhan 
dasar, sekarang dalam kebutuhan yang lain terkadang mau tidak mau harus dipenuhi, hal ini tidak terlepas pengaruh media yang menawarkan hal yang membuat masyarakat termakan oleh konsumsi media, gaya hidup. Anak utamanya memenuhi kebutuhannya sendiri, karena orang tua tidak dapat memenuhi kebutuhan anak sehingga anak berinisiatif untuk mencari kebutuhan sendiri, dalam hal itu anak dapat membantu orang tua-nya. Pada umumnya anak dalam keluarga petani telah cenderung membantu dalam mengelolah lahan pertanian mereka,umumnya petani bekerja disawah dengan sistem menanam yang dilakukan pada umumnya dua kali dalam setahun, dari semua orang kadang mengajarkan anaknya sejak dini untuk membantu di Sawah dengan harapan kerjanya ringan dan mendapatkan hasil pertanian yang melimpah.

Anak dalam keluarga petani lebih banyak membantu pada tanam atau musim panen, dalam perawatan, pemeliharaan pupuk selama menunggu hasil adalah kerja orangtua. Dalam sela aktivitas sambil menunggu hasil pengelolaan hasil panen waktu itu banyak anak mencari pekerjaan yang lain, bagi anak yang tidak sekelolah, agar dapat penghasilan yang dapat membantu meringankan kebutuhan keluarga. Mulai memelihara hewan seperti ayam, sapi,kambing dan kuda, sampai mencari kerja sampingan yang tidak begitu mengikat, seperti menjadi buruh. Peran anak putus sekolah sangat terlihat di Desa kampung Beru Kabupaten Takalar terbukti dengan aktivitas sehari-hari yang dilakukan oleh para anak yang putus sekolah adalah membantu pekerjaan orang tua mulai dari pekerjaan rumah, membantu orang tua disawah ataupun menjadi buruh kasar seperti buruh bangunan dan buruh tebang tebuh.

\section{KESIMPULAN}

Berdasarkan hasil penelitian yang telah disajikan dalam pembahasan pada bab terdahulu, maka dapat ditarik kesimpulan bahwa ada beberapa faktor yang menjadi penyebab terjadinya phenomena putus sekolah yang marak terjadi di Desa Kampung beru Kabupaten Takalar. Selain letak Desa yang sedikit terpencil hal lain yang takkalah penting adalah pemahaman sebagian masyarakat akan pentingnya pendidikan masih sangat kurang, Namun selain faktor yang disebutkan di atas, masih ada lagi faktor yang lebih mendominasi penyebab terjadinya putus sekolah yang terjadi di Desa Kampung Beru Kabupaten Takalar yaitu kemiskinan, sedangkan peran sosial anak dalam membantu ekonomi keluarga yaitu anak bekerja di sawah untuk membantu pekerjaan orang tua namun selain membantu pekerjaan di sawah anak juga mempunyai pekerjaan lain dengan harapan untuk memenuhi kebutuhan ekonomi keluarga. 


\section{DAFTAR PUSTAKA}

Ahmadi, Abu. (1989). Ilmu Sosial Dasar. Jakarta : Rineka Cipta.

Gilbert, Alan \& Gugler, josep. (1996). Urbanisasi dan Kemiskinan (di Dunia ketiga). Yogyakarta : PT. Tiara Wacana Yogya.

Khairuddin H.SS. (1997). Sosiologi Keluarga, Yogyakarta : Liberty

Lawang, Robert M. Z. (1986). Teori Sosiologi Klasik dan Modern. Jakarta : Gramedia.

Maleong, Lexy. (2010). Metode Penelitian Kualitatif. Jakarta : Rosdakarya

M, Setiadi, Elly \& Usman, Kolip. (2011). Pengantar Sosiologi Pemahaman Fakta dan Gejala Permasalahan Sosial (Teori, Aplikasi, dan Pencerahannya). Jakarta : Kencana Perdana Media Group.

Narkowo Dwi J, Suyanto Bagong, (2004). Sosiologi Teks Pengantar dan Terapan, Jakarta, Penerbit: Kencana.

Prof. H. Garna, Ph.D. Judistira K. (1996). Ilmu-ilmu Sosial Dasar-Konsep-Posisi. Bandung: Program Pascasarjana Universitas Padjadjaran.

Prof. DR. Nasution S. (2011). Sosiologi pendidikan (Interaksi Peserta Didik dan Lingkungannya). Makassar : Inninnawa.

Ritzer, George. (2010). Cet Ke 8. Sosiologi Ilmu Pengetahuan Berparadigma Ganda. Jakarta: Raja Grafindo Persada.

Salman, Darmawan. (2012). Sosiologi Desa (Revolusi Senyap Dan Tarian Kompleksitas). Makassar : Ininnawa

Soekanto, Soejono.(1990). Sosiologi Keluarga, Jakarta: Rineka Cipta.

Soekanto, Soerjono. (2012). Sosiologi Suatu Pengantar. Jakarta: Raja Grafindo Persada.

Tirtarahardja dan La Sulo. (2008). Pengantar Pendidikan. Jakarta : Rineka Cipta.

Yuliati, Yayuk. (2003). Sosiologi Pedesaan. Yogyakarta : Lappera Pustaka Utama. 